\title{
Reframing educational enhancement at University College London
}

\section{Jenny Marie}

This chapter explores different perspectives and dimensions of implementing educational change. It does so by applying Bolman and Deal's (1997) four frames theory to attempts to enhance education at University College London (UCL) between 2013-2018. Bolman and Deal (1997) identify four ways of viewing organisations: the symbols that indicate what the organisation values; the coalitions of stakeholders that fight for resources; the way the organisation is structured; and the skills, rewards and motivations of staff. These viewpoints are applied to educational change at a research-intensive university, UCL, following its recruitment of a new Provost, who promised to make the institution as renowned for its education as its research. This enables the identification of a number of lessons for educational change at an institutional level.

\section{Reframing Organisations}

Bolman and Deal (1997) argue that organisations can be thought of structurally: considering the principles underlying the way labour is divided within the institution and how divisions are co-ordinated to ensure everyone is working towards the same goals. They can be thought of as political arenas, where stakeholders vie for power and resources by building alliances. They can be thought of in terms of how the best is brought out of the organisation's personnel; and finally, as cultures, where people seek meanings from their work and to understand the values of the organisation. Reframing has been shown to be useful for increasing awareness of different ways of thinking about organisations (Dunford and Palmer, 1995). The four frames theory has therefore been selected for this chapter, in order to facilitate an exploration of the multiple influences and actors that affect organisation change at universities. UCL provides a good case study for this because of the myriad of educational changes it has undergone in recent years as its senior management battles a culture of research being valued above education.

UCL is considered to be one of the world's leading research-intensive universities and it proudly portrays this face to the world: its website states it was the top-rated UK university for research strength in the 2014 Research Excellence Framework, that is was ranked $10^{\text {th }}$ in 
the 2019 QS World University Rankings and that there are 29 Nobel laureates amongst its alumni, current and former staff (UCL, 2019). It is based in the centre of London and currently has over 38,000 students, over half of whom are postgraduate. In September 2013, a new Provost, Michael Arthur, was appointed promising to make UCL as renowned for its excellent teaching as its research. This chapter looks at the symbolic, political, structural and human resource changes that the university made between 2013-2018 in its bid to achieve this. The success of these initiatives are still in doubt at the time of writing: the institution gained silver in the Teaching Excellence Framework in 2017, in the face of student satisfaction levels below its benchmark for academic support and assessment and feedback (UCL, 2017).

\section{Symbolic frame}

Symbols indicate what is important - "they help people find meaning, purpose and passion" (Bolman and Deal, 1997, 217). In 2014, UCL created a new 20-year strategy, UCL2034. In this, UCL sets out its aim to become a world leader for 'research-based education' via its Connected Curriculum framework. Research-based education and the Connected Curriculum in particular were symbols of the increasing importance of education at UCL. They were intended to be non-threatening by highlighting the continued significance of research, and the Connected Curriculum was portrayed as flexible to the interpretations and needs of different departments. The Connected Curriculum was a successful symbol until the Director of UCL's academic development unit, who was strongly associated with the initiative, left UCL in 2018. When, shortly afterwards, the Connected Curriculum steering group and working groups were closed, this was taken as a sign by many that the initiative was no longer in favour. A salient point in the strength of symbolic actions. Research-based education in contrast has retained its prominent position in discussions, perhaps because it is commonly misunderstood amongst the university community as simply linking research and teaching, which is both a welcome message and one that is easily understood.

Alongside the Connected Curriculum in 2014, UCL ChangeMakers was established to enable students to make their ideas for enhancing education a reality. It formed a symbol of the importance of students and educational enhancement to the institution, as the main funding for such work was subsumed under the scheme. UCL ChangeMakers also had its steering group shut in 2018 and was subject to a review process. In contrast to the Connected Curriculum, it has emerged from this a larger, more embedded scheme. This was due to the 
strong support of its stakeholders but a notable difference from the Connected Curriculum was the symbolism around it at the time: rather than a narrative of loss, it had one of success, as its director had just won UCL's first National Teaching Fellowship.

UCL Arena, established slightly earlier, performed the complimentary purpose to UCL ChangeMakers of symbolising the importance of educators, by providing them with educational development opportunities and recognition through fellowship of the Higher Education Academy (HEA; now AdvanceHE). The importance of developing as an educator was itself symbolised by the award of Principal Fellowship of the HEA (PFHEA) to the Provost and the Vice Provost (Education \& Student Affairs). The Provost wrote in an AdvanceHE news item: "What better way to demonstrate my commitment to excellent teaching" and continued that he had wanted to signal UCL's focus on excellent teaching (Arthur, 2018).

Finally, the shift of the academic development unit from the ground floor to the tenth floor was symbolically important. Powerful departments are often situated at the top of buildings (Traweek, 2009). The department's surroundings changed from dark, dreary and unwelcoming to having a view across London that attracts visitors.

\section{Political frame}

The political frame focuses on the power dynamics and vested interests of stakeholders. Organisations consist of coalitions that fight for scarce resources (Bolman and Deal, 1997, $163)$; in this case money and staff time.

Looking at the wider political context, the UK government has been promoting the importance of education at universities throughout the century. The National Student Survey was introduced in 2005 , to enable students to make informed choices about where to study. The increase in home student fees in 2012 up to $£ 9000$ was intended to create a market-place of institutions to push up educational standards (Browne, 2010, p.8) and inter-institutional competition was further enabled in 2015 by removing the cap on home student numbers (Hillman, 2014). The government further incentivised the prioritisation of education, through the introduction of the Teaching Excellence Framework (TEF) in 2016-17, with the prospect of subject-level TEF from 2019-21.

UCL has been influenced by this wider political environment, working to raise NSS satisfaction rates since 2010/2011. Nevertheless, between 2013-18 this motivation for enhancing education was downplayed. The introduction of neo-liberal economics into Higher 
Education has been highly controversial with both students and staff (e.g. Wenstone, 2012; Neary \& Winn, 2009; Dunne, Zandstra, Brown \& Nurser, 2011). The continued dispute about the place of neo-liberal economics in HE was symbolised in the 2018 UCU strikes over USS pensions, which led to numerous protests against marketisation (Toope, 2018). On an organisational political level, disowning these motives for enhancing education and emphasising instead that it was values-led (Fung, 2017) was intended to increase staff buy-in.

Despite this apparent rejection of external political motivations, the external world has been used politically. Actor-network theory argues that facts are created by building a network of people and objects that validate the fact (Sismondo, 2010). An example of powerful actors in such a network are textbooks, which widely disseminate the fact and would require rewriting if it was disputed. In 2017 the then Director of the academic development unit, Dilly Fung, published her book, A Connected Curriculum for Higher Education, which has been downloaded over 13,000 times and she gave numerous keynotes. In doing so, she recruited the book's readership and presentation audiences into her network, collectively making the idea that the Connected Curriculum is an excellent education strategy that is at the core of UCL's education into a 'fact'. While this external narrative supported the Connected Curriculum's place at UCL while Fung was at the institution, it also strengthened the association between Fung and the initiative. As discussed, this meant that her departure from UCL was seen symbolically as the loss of the Connected Curriculum and this internal narrative was stronger than the external narrative of its excellence.

Finally, central UCL units built coalitions to forward education. The academic development unit worked with the Students' Union UCL, regularly consulting it on educational initiatives and co-delivering the institution's Education and Student Choice Awards. UCL's Digital Education worked to develop a digital environment that would support the Connected Curriculum; and HR were consulted to improve joint working on probationary requirements and leadership training. Academic Services worked with the unit to develop a new annual review (ASER), which is discussed in the structural frame section. Academic members of staff were also recruited on secondments as Connected Curriculum Fellows to advocate for the initiative and drive it forward in their local context.

\section{The Structural Frame}

The structural frame focuses on how the institution is organised to undertake its work. There are six assumptions (Bolman and Deal, 1997, pp. 39-40): 
1. Organisations exist to achieve predefined goals and objectives

2. Organisations work best when organised according to rational principles

3. Structures should fit the organisation's circumstances

4. Specialisation and division of labour increase efficiency

5. Forms of co-ordination and control are necessary to ensure that everyone works towards the same goals

6. Inefficiencies arise from structural problems that can be resolved by restructuring. Universities do not meet these all of assumptions very comfortably - they have multiple, ill-defined goals around research, education and knowledge exchange, which makes the achievement of goals hard to measure. (Bolman and Deal, 1997, pp. 48-56). They employ well educated staff, whose work is judged by academic peers rather than their line manager. Staff often feel a stronger sense of membership to their discipline than their institution, as they share the discipline's goals and the members of it judge and reward their work (Barnett, 2005, p.68). Further complicating matters, education and research are complex processes that are not open to standardisation. This means universities are usually decentralised and as a result, struggle to co-ordinate work across the entire institution and to control the quality of the work.

While a high degree of control exists at departmental level in universities, students often take modules from different departments and so are exposed to variable teaching quality and different methods of administration, such as the use (or non-use) of e-assessment. UCL has tried to coordinate teaching practices across the institution by mandating actions in its Annual Student Experience Review (ASER) process. The ASER process was introduced in 2015-16, and involves departments reviewing key UK data sets, such as the National Student Survey, Widening Participation data and Destination of Leavers of Higher Education; and then developing an enhancement plan for the year. To enhance teaching practice in a coordinated fashion across the university, mandated actions were introduced into the ASER development plan, such as creating a departmental feedback proforma and explaining criteria prior to every assessment. As such UCL has used action planning to specify how departments should increase teaching quality and to provide vertical coordination between departments (Bolman and Deal, 1997, pp. 42-43). However, the ASER process has faced challenges - in particular, actions that are not completed in the year are often lost and departments are unclear whether they need to continue mandated actions regarding process in future years. This has weakened the power of this co-ordination method. Recently, there has also been a backlash against the mandated actions because a number of 
them (e.g. benchmarking against UCL's Connected Curriculum and the completion of an Inclusive Curriculum Health Check) have been seen as information collecting rather than enhancement tools and there is a sense that department-specific priorities are being side-lined by the mandated actions.

UCL has also tried to introduce clearer standard operating procedures by revising its Academic Manual. Many of the changes have been designed to make the manual clearer and easier to follow. However, from 2018-2019 there are no longer any derogations from the regulations, though variations are allowed within approved parameters (UCL, 2018f). This is because the manual aims to "set and maintain the academic standards of UCL; promote transparency and consistency across faculties and departments, ensuring that all students are treated fairly and equally." (UCL, 2018b) There have also been new regulations: one major change has been the introduction of late summer assessments for students who fail a limited number of modules. This was introduced in 2017-18 "to improve the student experience and better align UCL with the rest of the UK higher education sector" (UCL, 2018d). As discussed below, this has caused contention amongst staff used to having the summer as research-time.

During 2017, UCL also began to implement an Academic Model Project. The academic model defines how curriculum data is structured and linked in UCL's student administration (SITS) system. The model is being updated to reflect changes in internal regulations and external requirements such as those of the Competition and Markets Authority. This should allow the administration system to better support module choice for students and provide staff with accurate data about their modules, such as the number of students who have enrolled (UCL, 2018h). However, as discussed below this has required UCL's VLE, Moodle, to be updated with short-notice, resulting in discontent amongst teaching staff.

UCL has also planned a restructure of the responsibilities for education. It mandated that every programme should have a named programme leader and a strand of Arena training was provided specifically for programme leaders. While the training strictly falls under the Human Resources frame (see below), the introduction of programme leaders and their training supported a wider structural move to plan and think in terms of programmes rather than modules. Modules tend to be the unit of educational planning and enhancement because they are taken by students on a range of programmes; they may be taught/designed by a single individual; and all have a module lead. The Connected Curriculum tried to shift this thinking by placing a focus on connections between the learning students were doing across 
subjects and levels (dimensions 3 and 6). UCL also began to use the TESTA method (TESTA, 2018) to aid staff in planning and enhancing assessment at a programme level; and its Digital Education team designed the Arena Blended Connected Curriculum (ABC) workshop (UCL, 2018a) to support planning the use of a range of learning methods across a programme.

The introduction of programme leaders was seen as the starting point for ensuring accountability for educational quality. A plan for Education Transformation was put forward to the Senior Management Team (SMT) in June 2018. This proposed new responsibilities for Vice Deans (Education) and Faculty tutors; and new roles of Directors of Education and Student Success within departments. These roles would have accountability for the quality of education at departmental and faculty levels. However, the decentralisation of power has made progress on this slow, as such changes require agreement across the whole institution.

\section{Human Resources Frame}

The Human Resources Frame “regards people's skills, attitudes, energy, and commitment as vital resources capable of either making or breaking an enterprise." (Bolman and Deal, p.101).

Bolman and Deal (1997, p. 130) cite Hackman and Oldham's (1980) work arguing that individuals need to see their work as meaningful. Fung took a values-based approach in her advocation of education at UCL, arguing that education is "the development of new understandings and practices, through dialogue and human relationships, which make an impact for good in the world" (Fung, 2017, p. 17). She further argued that empowering students to learn through participating in research and enquiry, would enable education AND research to "contribute more effectively to the global common good." (ibid, p. 3) Thus, UCL attempted to intrinsically motivate its staff to value education.

UCL also added a number of extrinsic motivating factors. Theory Y model of human behaviour is that the best way to get staff to work productively towards the institution's goals is to align their interests with those of the organisation. In other words, staff need to be rewarded and recognised for the work that the organisation values. (Bolman and Deal, 1997, p. 106). UCL has aimed to do this by revising its promotions framework to give education the same weighting as research. Drawing on research by the HEA (Fung and Gordon, 2016; Promoting teaching project team, 2013), UCL created a strengths-based approach to 
promotion; whereby staff could make cases based mainly on their education or their research (UCL, 2018g).

UCL further tried to create parity of esteem between education and research by introducing a professorial teaching fellow role, allowing teaching fellows to be promoted to grade 10 on the basis of their education work. The first group of people to be promoted to professorial teaching fellow gained this recognition in 2018, and have been drawn on as symbols of the reward that teaching can lead to (see: UCL, 2018e).

Further reward comes from UCL's Education and Student Choice awards. While UCL had these prior to 2013, since 2017 recipients have been eligible to enter a further selection process to be put forward for a National Teaching Fellowship or Collaborative Award for Teaching Excellence and UCL gained its first National Teaching Fellowship in 2018. Again, the achievement was used to symbolise the shift in UCL's priorities towards education and to inspire others to achieve this recognition (UCL, 2018c). Recognition of education work was also made possible for all, through the introduction of a mechanism by which all staff can apply for recognition with the HEA.

Training has been provided to support the new roles and structures that UCL has introduced. As discussed in the structural frame section, training has been introduced for programme leaders. UCL is also currently developing provision for Educational Leaders, which will support staff taking on the new educational leadership roles that are under development.

\section{Discussion}

Bolman and Deal (1997, p.278) argue that effective managers and leaders use multiple frames. UCL has made changes in line with all four of the frames in order to enhance its educational provision with varying levels of success. On many occasions changes in one frame supported those in another. For example, UCL ensured that the new educational roles it developed structurally had associated development opportunities through the HR frame. As Bolman and Deal (1997, p.320) argue "Retraining people without revising roles or revamping roles without retraining people never works." The success of staff through the new rewards and recognition frameworks has also been used symbolically. UCL's Connected Curriculum initiative served a symbolic role about the importance of education through the political allegiance it formed between education and research and with academic staff seconded into the academic development unit; it drew on structural changes such as the ASER process to 
operationalise itself through a benchmarking exercise; and provided a values-based argument to make educational work meaningful.

The frames, however, do not always support each other. Structural changes to enhance education at UCL have come at a cost to staff. Staff had spend time providing information for the Academic Model project, adjust to new module codes and as a result of these, a new version of their VLE (Moodle). The late summer resits have cut into the time they normally have for research and the ASER process is seen as increasingly burdensome with compulsory benchmarking statements and mandated actions that are sometimes seen as irrelevant. Addressing structural inconsistencies has therefore come at the cost of staff autonomy and their role in decision making. In May 2017, a staff survey among members of academic board revealed low morale, with comments that academic staff did not feel valued and 68\% disagreeing that UCL was well managed (Weale, 2017). In February 2018, a motion of no-confidence was passed against UCL's leadership at an informal meeting, with one academic saying: "management appeared now to be there to impede academics' work." (Wright, 2018)

Bolman and Deal (1997, p.71) argue that professional bureaucracies (such as universities) suffer chronic tension between administrators and the professional staff. At UCL this is reflected in the comments made in the academic board survey stating that "power was now in the hands of sometimes inexperienced administrators." (Weale, 2017). In other words, to advance education in a short period, UCL has taken power from its academic staff and given it to its technostructure.

At UCL the first changes were to the people in senior management positions - the Provost, Director of the academic development unit, Academic Services and Registrar. Following that, these key people began by making symbolic changes - the introduction of a new UCL2034 strategy and initiatives to symbolise the importance of education (Connected Curriculum), students (UCL ChangeMakers) and staff (UCL Arena). As Bolman and Deal $(1997$, p.240, 242) point out it is easier to address problems symbolically than in reality and so strategies often bear little relation to operational decisions. Though the political frame was addressed next, this arguably paid more attention to central units cooperating and to the external world, than to academics. While the hard work of structural changes to roles and processes and the promotion framework followed, the structural changes often came at a cost to staff, leading them to feel devalued. While the political work had been done to enable the changes to be pushed through and were supported by HR changes, on reflection it had not have been done sufficiently to bring academics along with the changes. It is likely that this is 
a difficult challenge in academia, where decentralisation arises from the professional nature of staff and where the main goals of the organisation (research, education, knowledge exchange) are disputed.

\section{Conclusion}

UCL's path in enhancing education, viewed through Bolman and Deal (1997)'s four frames, offers a number of lessons for other institutions:

1. To affect lasting change all four frames will need to be addressed: staff need to be rewarded for the things that the institution values and the institution needs to provide clear guidance and symbols as to what these are. Staff need training for new roles and structures. The structures need to support accountability and ensure co-ordination as students take modules across departments. Units need to work together to bring about co-ordinated change.

2. It is easier to begin change at the level of symbols and politically than structurally and through HR. Symbols are relatively easy to create, though the formation of a new strategy and by senior managers spending time acting in accordance with the values they wish others to adopt. UCL achieved this through its UCL2034 strategy and its Provost obtaining Principal Fellowship of the HEA. Politically, central units can come together by ensuring that there is dialogue and an alignment of their goals.

3. When a change is being made in one frame, consideration needs to be paid to how it will affect other frames. At UCL this was shown by the alienation of staff due structural changes, such as late summer resits.

4. When a change is being made in one frame, opportunities should be sought to support it through other frames. For example, UCL supported new programme leaders and education leaders through training; it used staff that gained new forms of recognition as symbols; and it drew on the power of research to enhance its education.

5. Symbols are important: they can support educational initiatives as occurred for both UCL ChangeMakers and UCL Arena; through the receipt of a National Teaching Fellowship associated with UCL ChangeMakers and the Provost's receipt of a Principal Fellowship of the HEA through UCL Arena. However, universities must also be alert to what symbols they may be unintentionally creating both in the present and potentially for the future. This is best shown by the unintended consequence of the Connected Curriculum steering group's closure being seen as a sign that it was no 
longer valued. The strong association that had built up between the Director of the academic development unit and the Connected Curriculum also created the potential for the symbol of its loss with her departure from the institution.

6. All stakeholders need to be meaningfully engaged for lasting change. Though structural changes can be pushed through with political coalitions of central units, this may cause an 'us and them' mentality, which will be unproductive in the long-term.

\section{References}

Arthur, M. 2018. Talking teaching: Why I became an HEA Fellow, by Professor Michael Arthur. [online] York: AdvanceHE. Available from:

https://www.heacademy.ac.uk/blog/talking-teaching-why-i-became-hea-fellow-professormichael-arthur [Accessed 7 December 2018).

Barnett, R. 2005. Reshaping the University. (Maidenhead: SRHE and Open University Press).

Bolman, L.G. \& Deal, T.E. 1997. Reframing Organisations: Artistry, Choice and Leadership. $2^{\text {nd }}$ ed. San Francisco: Jossey-Bass.

Browne, J. 2010. Securing a Sustainable Future for Higher Education. [online] Available from:

https://assets.publishing.service.gov.uk/government/uploads/system/uploads/attachment_data /file/422565/bis-10-1208-securing-sustainable-higher-education-browne-report.pdf

[Accessed 10 December 2018].

Dunford, R.W., \& Palmer, I.C. 1995. Claims about frames: Practitioners' assessment of the utility of reframing. Journal of Management Education, 19 (1), pp. 96-105.

Dunne, E., Zandstra, R., Brown, T., \& Nurser, T. 2011. Students as change agents: New ways of engaging with learning and teaching in Higher Education. [online] Bristol: ESCalate.

Available from: http://escalate.ac.uk/8242 [Accessed 25 September 2017]

Fung, D. 2017. A Connected Curriculum for Higher Education. London: UCL Press.

Fung, D. and Gordon, C. 2016. Rewarding educators and education leaders in researchintensive universities. [online] York: Higher Education Academy. Available from: https://www.heacademy.ac.uk/knowledge-hub/rewarding-educators-and-education-leaders [Accessed 23 July 2018]

Hackman, J.R. \& Oldham, G.R. 2010. Work Redesign. (Reading, Mass.: Addison-Wesley). Hillman, N. 2014. A guide to the removal of student number controls. HEPI Report 69. [online] Oxford: Higher Education Policy Institute. Available from: 
https://www.hepi.ac.uk/wp-content/uploads/2014/09/Clean-copy-of-SNC-paper.pdf

[Accessed 6 August 2018].

Neary, M., \& Winn, J. 2009. The student as producer: reinventing the student experience in higher education. In: Bell, L., Stevenson, H., and Neary, M. eds. The Future of Higher Education: Policy, Pedagogy and the Student Experience. London: Continuum, pp. 192-210. Promoting teaching project team. 2013. Promoting teaching: making evidence count. York:

Higher Education Academy. Available from: https://www.heacademy.ac.uk/knowledgehub/promoting-teaching-making-evidence-count [Accessed 25 July 2018]

Sismondo, S. 2010. An Introduction to Science and Technology Studies. $2^{\text {nd }}$ ed. (Malden, MA: Wiley-Blackwell).

TESTA. 2018. Transforming the Experience of Students through Assessment. [online]. Southampton: Southampton Solent University. Available from: www.testa.ac.uk [Accessed 10 December 2018]

Toope, S. 16 March 2018. The future of UK universities. Vice Chancellor's blog. [online] Cambridge: University of Cambridge. Available from: https://www.cam.ac.uk/news/thefuture-of-uk-universities-vice-chancellors-blog [Accessed 10 December 2018].

Traweek, S. 2009. Beamtimes and lifetimes. Cambridge, Mass.: Harvard University Press. Weale, S. 2017. UCL staff morale at all-time low because of management, poll finds. [online] The Guardian. 4 May. Available from:

https://www.theguardian.com/education/2017/may/04/ucl-staff-morale-at-all-time-lowbecause-of-management-poll-finds-academic-business-university Viewed 10 December 2018 [Accessed 10 December 2018]

Wenstone, R. 2012. A manifesto for partnership. National Union of Students (NUS). Available from: https://www.nusconnect.org.uk/resources/a-manifesto-for-partnership [Accessed 10 December 2018]

Wright, R. 2018. UCL academics back motion of no-confidence in how college is run. [online] 7 February. Available from: https://www.ft.com/content/82c44d7c-0c3f-11e8-8eb742f857ea9f09 [Accessed 10 December 2018]

UCL. 2017. UCL receives Silver in first year of Teaching Excellence Framework. [online] London: UCL. Available from: https://www.ucl.ac.uk/news/2017/jun/ucl-receives-silverfirst-year-teaching-excellence-framework-awards [Accessed 29 March 2019] UCL. 2018a. ABC Learning Design. [online] London: UCL. Available from: http://blogs.ucl.ac.uk/abc-ld/ [Accessed 10 December 2018] 
UCL. 2018b. About. [online] London: UCL. Available from:

https://www.ucl.ac.uk/academic-manual/about [Accessed 10 December 2018]

UCL. 2018c. Jenny Marie is UCL's first National Teaching Fellow. [online] London: UCL. Available from: https://www.ucl.ac.uk/teaching-learning/news/2018/sep/jenny-marie-uclsfirst-national-teaching-fellow [Accessed 10 December 2018]

UCL. 2018d. Late Summer Assessments. [online] London: UCL. Available from:

https://www.ucl.ac.uk/academic-manual/recent-changes/late-summer-assessments-2018-19 [Accessed 10 December 2018]

UCL. 2018e. My route to Professional Teaching Fellow. [online] London: UCL. Available from: https://www.ucl.ac.uk/teaching-learning/case-studies/2018/sep/my-route-professorialteaching-fellow [Accessed 14 December 2018].

UCL. 2018f. Recent Changes. [online] London: UCL. Available from:

https://www.ucl.ac.uk/academic-manual/recent-changes [Accessed 10 December 2018]

UCL. 2018g. UCL Academic Careers Framework. [online] London: UCL. Available at:

https://www.ucl.ac.uk/human-resources/sites/human-resources/files/ucl-130418.pdf

[Accessed 12 December 2018]

UCL. 2018h. What is the Academic Model Project? [online] London: UCL. Available from: https://www.ucl.ac.uk/srs/amp/about [Accessed 10 December 2018]

UCL. 2019. Academic excellence with a global impact [online] London: UCL. Available from: https://www.ucl.ac.uk [Accessed 10 April 2019]

\section{Suggested Indexing Words}

Research-based education

Promotions framework

HEA Fellowships

Marketisation

Decentralisation

Restructuring

Leadership training

Education awards

Symbols

Power 